Further work is in progress for the determination of the possible association between these three antigenic determinants and their segregation in related individuals.

\section{Jan Hirschfeld}

State Institute for Blood Group Serology,

Statens Rättskemiska Laboratorium, Stockholm 60.

\section{B. S. BLumberg}

Geographic Medicine and Genetics Section, National Institutes of Health, Bethesda, Maryland.

\section{A. C. Aturison}

National Institute for Medical Research, London, N.W.7.

${ }^{1}$ Allison, A. C., and Blumberg, B. S., Lancet, i, 634 (1961).

2 Blumberg, B. S., Bernanke, D., and Allison, A. C., J. Clin. Invest., 41, 1963 (1962).

s Blumberg, B. S., Dray, S., and Robinson, J. C., Nature, 194, 656 (1962).

4 Blumberg, B. S., and Riddell, N., J. Clin. Invest., 42, 867 (1963).

slumberg, B. S., Alter, H. J., Riddell, Nancy M., and Erlandson, Marion, Vox Sang., 9, 128 (1964).

6 J Jundschuh, G., Geserick, G., Marek, Z., and Fünfhausen, G., Das Deutsche Gesundheitwesen, 18, 819 (1963).

' Blumberg, B. S., Ann. N.Y. Acad. Sci., 108, 1052 (1963).

${ }^{8}$ Hirschfeld, J., Science Tools, 10, 45 (1963).

9 Hirschfeld, J., and Blombäck, M., Nature, 201, 1337 (1984).

${ }^{10}$ Björklund, B., Proc. Soc. Exp. Biol. Med., 79, 319 (1952).

${ }^{2}$ Hirschfeld, J., Nature, 187, 126 (1960).

\section{Technique for obtaining the Plasma from a Drop of Blood}

DURING the investigation of plasma of laying hens, it was found necessary to obtain samples of approximately $0.03 \mathrm{ml}$. from large numbers of birds, and also from the same bird at frequent intervals. A technique was developed, in which centrifugation of the blood, to separate the cells from the plasma, was performed in the collection tubes. Transferring the blood is thereby avoided, and the plasma is obtained almost quantitatively.

The collection tubes are mada from clear vinyl capillary tubing of $1 \mathrm{~mm}$ diameter, cut into $20-\mathrm{cm}$ lengths. They are heparinized before use, by filling with a $1 \mathrm{mg}$ per ml. solution of heparin and drying at $90^{\circ} \mathrm{C}$. A similar number of support tubes are made from 5-mm diameter, white, vinyl insulation tubing, cut into 8-cm lengths, and marked for identification, using a ball-point pen. Alternatively, tubing of various colours may be used.

The bird is bled from the comb, using a blood lancet, and the blood allowed to flow into the collection tube, aided by suction if necessary. The tubo is then folded in half, inserted into a support tube and positioned with its fold levol with one end. The open ends of the collection tube will protrude about 1 em out of the support tube, which facilitates its extraction. When folded in this manner, the collection tube is constricted at its centre, which prevents any leakage of the sample during transportation to the laboratory. Sealing the tube is unnecessary.

The tubes are placed in Wintrobe hæmatocrit adaptors or packed into $50-\mathrm{ml}$. contrifuge tube holders and centrifuged at $2,000 \mathrm{~g}$ for $5 \mathrm{~min}$. The capillary tubes are removed from their support tubes and unfolded. The packed cells, which are in the centre of the tube, divide the plasma into two approximately equal samples The tube is transected with scissors at the cell boundaries, and the plasma expelled by a blast of air from a hypodermic syringe fitted with a 17-gauge needle.

$$
\begin{gathered}
\text { Department of Animal Husbandry, } \\
\text { University of Sydney. }
\end{gathered}
$$

Francis P. Moss

\section{HISTOLOGY}

\section{Myoepithelium in Mouse Prostate}

UNDER the light microscope prostatic acini are lined by tall columnar cells, usually in a single layer, with occasionally more homogeneous basal or 'reserve' cells ${ }^{1}$. The appearance under the electron microscope of the surface opithelium in the rodent prostate has been described by von Braunsteiner et al. ${ }^{2}$, Harkin ${ }^{3}$ and others ${ }^{4-7}$. Franks and Barton ${ }^{5}$ also described a special basal cell found in the space below the basoment membrane.

In recent work on normal mouse prostate, using $C 57$ black-and-tan mice aged 5-7 months, we have studied the basement membrane region under the electron microscope. The mice were killed by breaking the neck and the tissue fixed in Palade's fixative, dehydrated with alcohols and embedded in 'Araldite'. Thin sections, post-stained with lead by Karnovsky's method $A$ (ref. 8 ), were examined with a Siemens Elmiskop I at primary magnifications of $\times 1,060-20,000$.

In addition to the basal cells of Franks and Barton, we found another type of basal cell lying above the basement membrane (Fig. 1). These cells are fusiform, triangular or stellate, sometimes with processes extending along the basement membrane for a short distance. The nucleus, which occupies a large part of the cell, has a smooth margin in the fusiform and an indented margin in the triangular cells. Tho cytoplasm is comparable in density with the underlying smooth muscle and contains small bundles of filaments arranged approximatoly parallel to the cell walls. There are relatively few mitochondria, and the rough endoplasmic reticulum is poorly developed, but

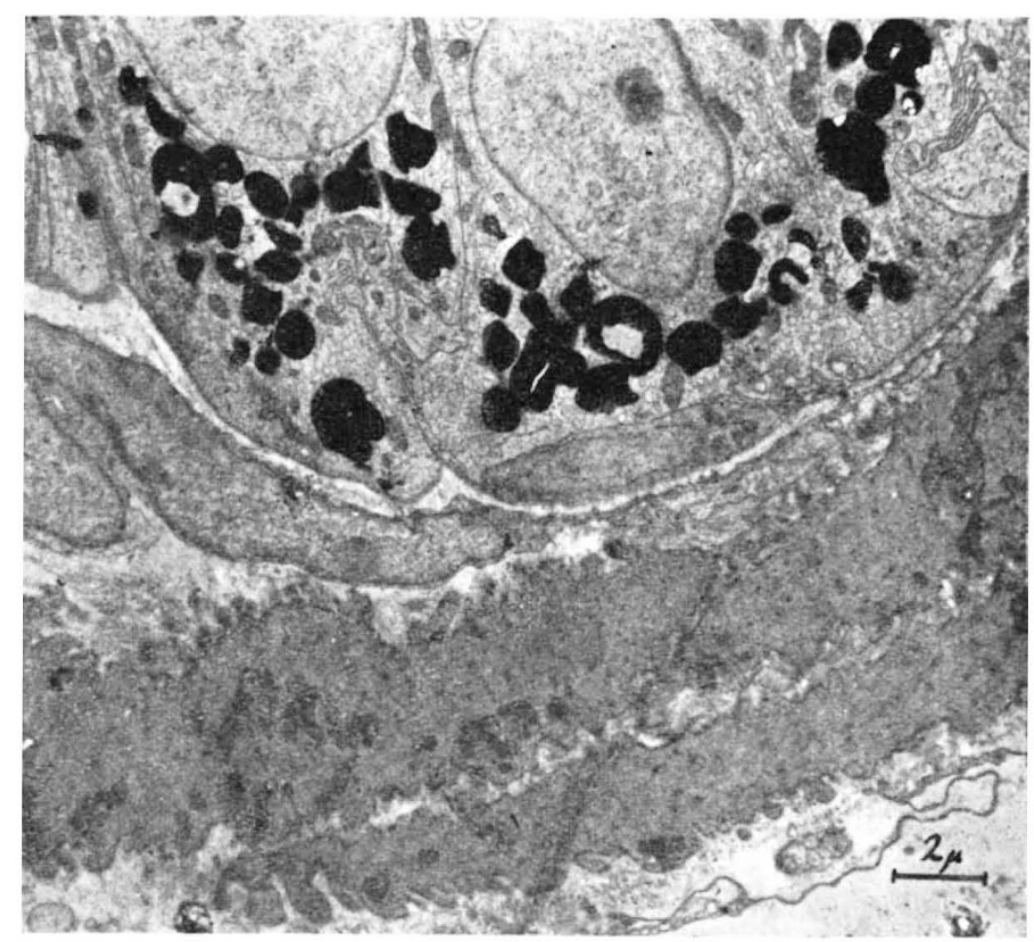

Fig. 1. An electron micrograph of the basal region of normal mouse ventral prostate epithelium. A typical fusiform myoepithelial cell lies above the basement membrane, a basal cellies between the basement membrane and the muscle cells below 